\title{
KORELASI KETERAMPILAN MEMAHAMI TEKS DESKRIPSI DENGAN KETERAMPILAN MENULIS TEKS DESKRIPSI SISWA KELAS VII SMP NEGERI 15 PADANG
}

\author{
Oleh: \\ Deta Fitrianita1 ${ }^{1}$, Syahrul R. ${ }^{2}$, Tressyalina ${ }^{3}$ \\ Pendidikan Bahasa dan Sastra Indonesia \\ FBS Universitas Negeri Padang \\ e-mail: detafitrianita03@gmail.com
}

\begin{abstract}
This article was written to find out the correlation between comprehension and writing skill of description text for student at class VII SMPN 15 Padang. Data in this study was score of text comprehension skill. The type of this study was quantitative research with correlation design. Study population was students at class VII SMPN 15 Padang that enrolled in academic year of 2016/2017 with sample was amounted to 224 students that dispersed in seven classes. Sampling determination used proportional random sampling technique that obtained 42 students (20\% from student population per class). Study fining showed that there was a significant correlation between comprehension and writing skill of description text for student at class VII SMPN 15 Padang with tcount > ttable (10.32 > 1.68). Therefore, to write description text students should be able to understand the description text it self.
\end{abstract}

Kata kunci: korelasi, keterampilan memahami teks deskripsi, keterampilan menulis teks deskripsi

\section{A. Pendahuluan}

Secara empiris, kemampuan membaca siswa Indonesia di dunia internasional masih lemah. Wahyuni (2009:180) memaparkan bahwa dari laporan Bank Dunia no 16369-IND dan studi IEA (International Association for the Evolution of Education Achievermen) di Asia Timur, menunjukkan bahwa minat terendah membaca anak-anak dipegang oleh negara Indonesia. Kajian PIRLS (Progress in International Reading Literacy Study) yaitu studi internasional dalam bidang membaca pada anak-anak di seluruh dunia yang disponsori oleh IEA ini menunjukkan bahwa rata-rata anak Indonesia berada pada urutan keempat dari bawah dari 45 negara di dunia.

Sesuai standar isi kurikulum 2013 untuk mata pelajaran bahasa Indonesia, kompetensi yang harus dikuasai peserta didik yakni memahami, menganalisis, mengevaluasi, menginterpretasi, memproduksi atau menulis, menyunting, mengabtraksi, dan mengkonversi (Kemendikbud, 2014:16). Kesembilan kompeternsi tersebut, memahami dan memproduksi atau menulis merupakan salah satu dari kompetensi tersebut. Oleh sebab itu, memahami dan menulis merupakan dua hal yang saling berkaitan, termasuk memahami teks deskripsi dengan menulis teks deskripsi.

\footnotetext{
${ }_{1}$ Penulis Skripsi, Mahasiswa Prodi Pendidikan Bahasa dan Sastra Indonesia, wisuda September 2017

2 Pembimbing I, Dosen FBS Universitas Negeri Padang

3 Pembimbing II, Dosen FBS Universitas Negeri Padang
} 
Menuangkan sebuah gagasan menjadi sebuah tulisan diperlukan pengetahuan yang cukup. Pengetahuan diperoleh melalui kegiatan membaca. Membaca dapat memberi informasi dan menambah pengetahuan siswa. Dengan membaca, seseorang akan lebih mudah untuk menuangkan ide dalam bentuk sebuah tulisan, membaca menjadikan seseorang memiliki banyak bahan untuk menulis. Oleh karena itu, semakin banyak seseorang membaca maka akan semakin lancar dalam menulis. Sehubungan dengan itu, menurut Siswartini (2014:2), "Menulis adalah menyusun kata-kata menjadi kalimat secara benar sesuai dengan kaidah tata bahasa untuk menyampaikan pengetahuan atau menginformasikan tentang suatu objek yang saling berhubungan".

Pada lingkungan sekolah, siswa yang memiliki kebiasaan membaca dan memahami yang baik dipercaya akan memiliki kemampuan menulis yang baik pula. Siswa yang tingkat kebiasaan membaca dan memahami yang belum baik akan mendapatkan nilai keterampilan menulis yang kurang memuaskan. Menulis dan memahami bacaan mempunyai hubungan yang erat. Bila seseorang menuliskan sesuatu, maka pada prinsipnya seseorang menginginkan agar tulisannya itu dibaca oleh orang lain. Dengan demikian, pada dasarnya hubungan antara menulis dan membaca merupakan hubungan antara penulis dan pembaca. Hal itu sesuai dengan pendapat Langi, Tahir, dan Idris, (2015:89) menjelaskan bahwa siswa yang tidak mampu membaca dan menulis dengan baik akan mengalami kesulitan dalam mengikuti kegiatan pembelajaran pada semua mata pelajaran. Selain itu, siswa juga akan mengalami kesulitan menagkap dan memahami informasi yang disajikan dalam berbagai buku pelajaran. Hal ini akan berdampak pada kemajuan belajarnya, sehingga menjadi lamban jika dibandingkan dengan teman yang lainnya.

Kegiatan membaca sangat erat hubungannya dengan keterampilan menulis. Hal itu sejalan dengan pendapat Pujiono (2012:781), seseorang penulis akan mempunyai karakter dalam tulisannya sesuai dengan pengalaman yang diperolehnya ketika membaca. Tulisan yang baik akan diketahui dari seberapa luas isi/kajian yang diungkap oleh penulis dalam suatu teks.

Perlu diketahui bahwa setiap jenis teks memiliki struktur sendiri. Setiap struktur teks yang ada memiliki struktur berpikir masing-masing. Dengan demikian, semakin banyak jenis teks yang dipahami siswa, semakin banyak juga struktur berpikir yang bisa digunakan siswa. Pemahaman siswa mengenai teks harus segera disalurkan dalam bentuk tulisan. Untuk itu, perlu dilakukan latihan-latihan menulis agar pemahaman siswa lebih meningkat. Hal ini sesuai dengan pendapat Samniah (2016:1) menjelaskan bahwa keterampilan memahami dapat diperoleh dari pengetahuan tentang suatu hal yang dipelajari secara mendalam.

Berbagai jenis teks dipelajari oleh siswa di sekolah. Siswa dituntut untuk dapat menulis berbagai jenis teks yang memiliki struktur yang utuh. Untuk dapat menulis sebuah teks, siswa harus membaca dan memahami suatu bacaan dengan baik. Hal ini sejalan dengan pendapat Suyuno (20018:204) menjelaskan bahwa membaca-berpikir-menulis merupakan inti kegiatan yang sangat diperlukan siswa untuk menyelesaikan studi dan melanjutkan studi. Oleh karena itu, siswa dituntut untuk bisa memproduksi atau menulis sebuah teks yang baik.

Tujuan siswa menguasai berbagai jenis teks, yaitu sebagai sarana untuk menuangkan ide atau gagasannya. Salah satu teks tersebut adalah teks deskripsi. Teks deskripsi adalah salah satu bentuk teks yang harus dikuasai siswa di sekolah, khususnya di SMP. Siswa dituntut mampu untuk menulis teks deskripsi yang sesuai dengan karakteristik teks tersebut. Hal ini sesuai dengan kurikulum 2013 revisi KI 4 yaitu mencoba, mengolah, dan menyaji dalam ranah konkret (menggunakan, mengurai, merangkai, memodifikasi, dan membuat) dan ranah abstrak (menulis, membaca, menghitung, menggambar, dan mengarang) sesuai dengan yang dipelajari di sekolah dan sumber lain yang sama dalam sudut pandang/teori dan KD 4.2 yaitu menyajikan data, gagasan, kesan dalam bentuk teks deskripsi tentang objek (sekolah, tempat wisata, tempat bersejarah, dan atau suasana pentas seni daerah) secara tulis dan lisan dengan memperhatikan struktur dan aspek kebahasaan baik secara lisan dan tulis.

Pembelajaran bahasa Indonesia dalam Kurikulum 2013 adalah pembelajaran berbasis teks. Prinsip dasar pembelajaran berbasis teks adalah bahasa dipandang sebagai teks dan teks 
deskripsi merupakan teks yang dipelajari di kelas VII semester 1. Febriyeni (2014:5) menyatakan menullis teks deskripsi adalah menangkapkan objek yang diamati, diresapi diimajinasi dalam pikirannya dan dituangkan dalam bentuk tulisan atau menggambarkan sesuatu berdasarkan pengalam semua paca indra dengan kata-kata secara jelas dan terperinci. Dengan kata lai, deskripsi merupakan hasil observasi melalui panca indra yang disampaikan dengan kata-kata atau kalimat.

Teks deskripsi memiliki struktur dan ciri kebahasaan. Kosasih, dkk. (2016:20) menyatakan bahwa struktur teks deskripsi ada tiga, yaitu (1) deskripsi umum, yaitu bagian yang menggambarkan pernyataan umum sebuah topik yang berisi nama objek yang dideskripsikan, lokasi, sejarah lahirnya, dan makna nama sebuah objek. (2) Deskripsi bagian, yaitu bagian yang berisi gambaran secara lebih spesifik terkait topik teks deskripsi yang diperinci berdasarkan tanggapan subjektif penulis. Perincian dapat berisi apa yang dilihat, apa yang didengar, dan apa yang dirasakan penulis dengan mengamati objek tersebut. (3) Penutup, yaitu bersi kesimpulan dan kesan umum terhadap sesuatu yang dideskripsikan tersebut.

Ciri kebahasaan teks deskripsi juga terbagi tiga, yaitu (1) sinonim, Oktaviani, Aminah, dan Susanti (2009:38) menjelaskan bahwa sinonim adalah kata-kata yang memiliki makna yang hampir sama, namun tidak dapat saling digunakan pada konteks yang sama. (2) Kata depan (preposisi), Rozelin (2012:256) menjelaskan bahwa preposisi adalah salah satu dari kelas kata yang jumlahnya sangat beragam. Preposisi dapat dibedakan menjadi empat, yaitu preposisi $d i$, pada, dari, ke. (3) Majas, Zaimar (2002:45) menyatakan bahwa majas atau gaya bahasa adalah pemakaian gaya bahasa yang dapat menghidupkan apa yang dikemukakan dalam teks, karena gaya bahasa dapat mengemukakan gagasan yang penuh makna dengan singkat. Seringkali pemakaian gaya bahasa digunakan untuk penekanan terhadap pesan yang diungkapkan. Manaf (2010:125) menyatakan bahwa majas dapat dibedakan menjadi dua macam. Pertama, majas persamaan atau simile, digunakan untuk membandingkan sessuatu dan sifatnya eksplisit. Kedua, majas personifikasi, digunakan untuk memberikan sifat-sifat yang dimiliki manusia atau perilaku yang lazim dilakukan manusia kepada benda.

Berdasarkan pengamatan yang telah dilakukan di SMP Negeri 15 Padang, siswa kelas VII masih menemui beberapa kendala dalam menulis teks deskripsi. Kendala tersebut antara lain (1) siswa belum terampil menulis teks deskripsi sesuai dengan isi teks deskripsi; (2) siswa belum terampil menuliis teks deskripsi sesuai dengan struktur teks deskripsi, yaitu deskripsi umum, deskripsi bagian, dan penutup; (3) siswa belum terampil menulis teks deskripsi sesuai dengan ciri kebahasaan teks deskripsi yang sesuai dengan ciri kebahasaan teks deskripsi, yaitu sinonim, kata depan (preposisi), dan majas.

Permasalahan yang dihadapi siswa tersebut membawa pengaruh terhadap pembelajaran menulis teks deskripsi menjadi tidak efektif. Langkah yang harus dilakukan dalam menulis teks deskripsi adalah dengan memahami teks deskripsi. Hubungan keterampilan memahami suatu bacaan dengan keterampilan menulis sangat erat. Oleh karena itu, kedua keterampilan tersebut harus dilatihkan agar ditemukan relevansi dan hubungan positif yang signifikan. Selain itu, memahami dan menulis memiliki nilai penting bagi siswa dalam pembelajaran bahasa Indonesia di sekolah.

\section{B. Metode Penelitian}

Jenis penelitian ini adalah penelitian kuantitatif dengan menggunakan metode deskriptif melalui desain korelasional. Penelitian ini dikatakan penelitian kuantitatif karena informasi atau data yang diperoleh berupa angka, yaitu skor keterampilan memahami teks deskripsi dan skor keterampilan menulis teks deskripsi. Hal ini sesuai dengan pendapat Arikunto (2010:27) bahwa penelitian kuantitatif adalah penelitian yang banyak dituntut menggunakan angka, mulai dari pengumpulan data, penafsiran terhadap data, serta penampilan dari hasilnya.

Metode dalam penelitian ini adalah metode deskriptif. Nazir (2010:54), menyatakan bahwa metode deskriptif bertujuan untuk membuat deskripsi, gambaran atau lukisan secara sistematis, 
Korelasi Keterampilan Memahami Teks Deskripsi dengan Keterampilan Menulis Teks Deskripsi Siswa Kelas VII SMP Negeri 15 Padang-Della Melaty, Irfani Basri, M. Hafrison

faktual dan akurat mengenai fakta-fakta, sifat-sifat serta hubungan antarfenomena yang diselidiki.

Rancangan (desain) dalam penelitian ini adalah korelasional. Hal ini sejalan dengan pendapat Ibnu, Moehnilabib, Mukhadis, Suparno, Rafi'udin, dan Sukarnyana (2003:46) yang menyatakan bahwa rancangan penelitian korelasional bermaksud untuk mengungkapkan hubungan korelatif antarvariabel.

Sampel penelitian ini sebanyak 42 orang siswa kelas VII SMP Negeri 15 Padang yang yang tersebar dalam 7 kelas dan terdaftar pada tahun pelajaran 2016/2017. Instrumen yang digunakan dalam penelitian ini adalah tes objektif dan tes unjuk kerja. Tes objektif digunakan untuk mengukur keterampilan memahami teks deskripsi, berbentuk pilihan ganda dengan empat pilihan jawaban kepada sampel (A, B, C, dan D). Tes unjuk kerja digunakan untuk mengumpulkan data keterampilan menulis teks deskripsi siswa kelas VII SMP Negeri 15 Padang. Tes unjuk kerja ini berbentuk penugasan kepada siswa untuk memproduksi teks deskripsi sesuai dengan tema yang ditentukan.

\section{Hasil dan Pembahasan}

\section{Keterampilan Memahami Teks Deskripsi Siswa Kelas VII SMP Negeri 15 Padang}

Langkah-langkah yang dilakukan dalam menganalisis data penelitian ini adalah sebagai berikut. Pertama, menganalisis keterampilan memahami teks deskripsi siswa kelas VII SMP Negeri 15 Padang secara umum dan per indikator. Kedua, menganalisis keterampilan menulis teks deskripsi siswa kelas VII SMP Negeri 15 Padang secara umum dan per indikator. Ketiga, menganalisis hubungan keterampilan memahami teks deskripsi dengan keterampilan menulis teks deskripsi siswa kelas VII SMP Negeri 15 Padang

Data keterampilan memahami teks deskripsi diperoleh melalui tes objektif tipe pilihan ganda dengan empat alternatif jawaban (A, B, C, dan D). Tes tersebut berjumlah 40 butir soal dengan tiga indikator yang diuji. Indikator yang dimaksud, yaitu memahami isi teks deskripsi terdiri atas 15 butir soal, memahami struktur teks deskripsi terdiri atas 13 butir soal, dan memahami ciri kebahasaan teks deskripsi terdiri atas 12 butir soal. Dari 40 butir soal yang diujikan tersebut, skor tertinggi yang diperoleh siswa adalah 39 dan skor terendah adalah 27.

Keterampilan memahami teks deskripsi siswa kelas VII SMP Negeri 15 Padang secara umum tergolong baik karena rata-rata keterampilan memahami teks deskripsi siswa berada pada tingkat pemahaman $76-85 \%$ pada skala 10.

Keterampilan memahami teks deskripsi siswa kelas VII SMP Negeri 15 Padang secara umum adalah sebagai berikut. Pertama, siswa yang memperoleh nilai keterampilan memahami teks deskripsi dengan kualifikasi sempurna berjumlah 1 orang (2,38\%). Kedua, siswa yang memperoleh nilai keterampilan memahami teks deskripsi dengan kualifikasi baik sekali berjumlah 8 orang $(19,05 \%)$. Ketiga, siswa yang memperoleh nilai keterampilan memahami teks deskripsi dengan kualifikasi baik berjumlah 21 orang $(50,00 \%)$. Keempat, siswa yang memperoleh nilai keterampilan memahami teks deskripsi dengan kualifikasi lebih dari cukup berjumlah 12 orang $(28,57 \%)$.

Ditinjau dari masing-masing indikator, keterampilan menulis teks deskripsi siswa kelas VII SMP Negeri 15 Padang adalah sebagai berikut. Pertama, Indikator 1 (memahami isi teks deskripsi). Indikator memahami isi teks deskripsi dengan nilai rata-rata 79,84 berada pada kualifikasi baik. Nilai rata-rata untuk indikator memahami isi teks deskripsi berada pada kualifikasi baik hal ini dikarenakan siswa tersebut telah paham mengenai bentuk isi teks deskripsi yang diujicobakan melalui keterampilan memahami teks deskripsi. siswa telah mampu menjawab pertanyaan yang berhubungan dengan isi teks deskripsi melalui ketrampilan memahami teks deskripsi.

Skor yang diperoleh siswa untuk indikator isi teks deskripsi yaitu sebagai berikut. Siswa yang mendapat nilai 100,00 berjumlah 6 orang $(14,29 \%)$, berada pada kualifikasi sempurna. Siswa yang mendapat nilai 93,33 berjumlah 8 orang $(19,05 \%)$, berada pada kualifikasi baik 
sekali. Siswa yang mendapat nilai 86,67 berjumlah 5 orang $(11,90 \%)$, berada pada kualifikasi baik sekali. Siswa yang mendapat nilai 80,00 berjumlah 6 orang $(14,29 \%)$, berada pada kualifikasi baik. Siswa yang mendapat nilai 73,33 berjumlah 5 orang $(11,90 \%)$, berada pada kualifikasi lebih dari cukup. Siswa yang mendapat nilai 66,67 berjumlah 4 orang $(9,52 \%)$, berada pada kualifikasi lebih dari cukup. Siswa yang mendapat nilai 60,00 berjumlah 5 orang $(11,90 \%)$, berada pada kualifikasi cukup. Siswa yang mendapat nilai 53,33 berjumlah 3 orang (7,14\%), berada pada kualifikasi hampir cukup.

Kedua, Indikator 2 (memahami struktur teks deskripsi). Indikator memahami struktur teks deskripsi dengan nilai rata-rata 83,33 berada pada kualifikasi baik. Bertolak dari nilai rata-rata tersebut, disimpulkan bahwa sebagian besar siswa sudah mampu memahami struktur teks deskripsi dengan tepat. Skor yang diperoleh siswa untuk indikator struktur teks deskripsi adalah sebagai berikut. Siswa yang mendapat nilai 100,00 berjumlah 8 orang $(19,05 \%)$, berada pada kualifikasi sempurna. Siswa yang mendapat nilai 92,31 berjumlah 9 orang $(21,43 \%)$, berada pada kualifikasi baik sekali. Siswa yang mendapat nilai 84,62 berjumlah 8 orang $(19,05 \%)$, berada pada kualifikasi baik. Siswa yang mendapat nilai 76,92 berjumlah 7 orang $(16,67 \%)$, berada pada kualifikasi baik. Siswa yang mendapat nilai 69,23 berjumlah 6 orang $(14,29 \%)$, berada pada kualifikasi lebih dari cukup. Siswa yang mendapat nilai 61,54 berjumlah 3 orang $(7,14 \%)$, berada pada kualifikasi cukup. Siswa yang mendapat nilai 53,85 berjumlah 1 orang $(2,38 \%)$, berada pada kualifikasi hampir cukup.

Ketiga, Indikator 3 (memahami ciri kebahasaan teks deskripsi). Indikator memahami ciri kebahasaan teks deskripsi dengan nilai rata-rata 78,37 berada pada kualifikasi baik. Hal ini disebabkan kurangnya pengetahuan siswa mengenai ciri kebahasaan teks deskripsi. skor keterampilan menulis teks deskripsi berdasarkan indikator ciri kebahasaan teks deskripsi adalah sebagai berikut. Siswa yang mendapat nilai 100 berjumlah 5 orang $(19,50 \%)$, berada pada kualifikasi sempurna. Siswa yang mendapat nilai 91,67 berjumlah 7 orang $(16,67)$, berada pada kualifikasi baik sekali. Siswa yang mendapat nilai 83,33 berjumlah 10 orang $(23,81 \%)$, berada pada kualifikasi baik. Siswa yang mendapat nilai 75,00 berjumlah 6 orang $(14,29 \%)$, berada pada kualifikasi lebih dari cukup. Siswa yang mendapat nilai 66,67 berjumlah 6 orang $(14,29 \%)$, berada pada kualifikasi lebih dari cukup. Siswa yang mendapat nilai 58,33 berjumlah 8 orang $(19,05 \%)$, berada pada kualifikasi cukup.

Berdasarkan hasil tersebut, disimpulkan bahwa rata-rata hitung keterampilan memahami teks deskripsi siswa kelas VII SMP Negeri 15 Padang yang tertinggi berada pada/indikator 2 (struktur teks deskripsi) dan terendah berada pada indikator 3 (ciri kebahasaan teks deskripsi). Berdasarkan uraian tersebut, dapat disimpulkan bahwa nilai rata-rata keterampilan memahami teks deskripsi siswa secara umum sebesar 80,54 dan berada pada kualifikasi baik.

\section{Keterampilan Menulis Teks Deskripsi Siswa Kelas VII SMP Negeri 15 Padang}

Berdasarkan data yang telah dianalisis, dapat diketahui keterampilan memahami teks deskripsi siswa kelas VII SMP Negeri 15 Padang. Skor yang telah diperoleh dari penganalisisan data, kemudian diubah dalam bentuk nilai. Perhitungan nilai untuk keterampilan memahami teks deskripsi untuk indikator memahami struktur teks deskripsi berpedoman pada rumus persentase. Nilai tersebut kemudian ditafsirkan ke dalam tabel konversi skala 10.

Penilaian keterampilan menulis teks deskripsi siswa kelas VII SMP Negeri 15 Padang ada tiga indikator yang dinilai. Pertama, Indikator 1 (memahami isi teks deskripsi). Indikator isi teks deskripsi dengan nilai rata-rata 80,16 berada pada kualifikasi baik. Skor yang diperoleh siswa untuk menulis teks deskripsi berdasarkan indikator isi teks deskripsi adalah sebagai berikut. Siswa yang memperoleh nilai 100,00 dengan kualifikasi sempurna berjumlah 11 orang (26,19\%). Siswa yang memperoleh nilai 83,33 dengan kualifikasi baik berjumlah 14 orang $(33,33 \%)$. Siswa yang memperoleh nilai 66,67 dengan kualifikasi lebih dari cukup berjumlah 15 orang $(35,71 \%)$. Siswa yang memperoleh nilai 50,00 dengan kualifikasi hampir cukup berjumlah 2 orang $(4,76 \%)$. 
Korelasi Keterampilan Memahami Teks Deskripsi dengan Keterampilan Menulis Teks Deskripsi Siswa Kelas VII SMP Negeri 15 Padang-Della Melaty, Irfani Basri, M. Hafrison

Kedua, Indikator 2 (memahami struktur teks deskripsi). Indikator struktur teks deskripsi dengan nilai rata-rata 82,94 berada pada kualifikasi baik. Skor yang diperoleh siswa untuk menulis teks deskripsi berdasarkan indikator kelengkapan struktur teks deskripsi adalah sebagai berikut. Siswa yang memperoleh nilai 100,00 dengan kualifikasi sempurna berjumlah 14 orang (33,33\%). Siswa yang memperoleh nilai 83,33 dengan kualifikasi baik berjumlah 14 orang (33,33\%). Siswa yang memperoleh nilai 66,67 dengan kualifikasi lebih dari cukup berjumlah 13 orang $(30,95 \%)$. Siswa yang memperoleh nilai 50,00 dengan kualifikasi hampir cukup berjumlah 1 orang $(2,38 \%)$.

Bertolak dari nilai rata-rata tersebut, disimpulkan bahwa sebagian besar siswa sudah mampu memahami struktur teks deskripsi. Berdasarkan penjelasan tersebut, untuk indikator struktur teks deskripsi rata-rata siswa telah mampu menuliskan struktur dengan tepat. Sesuai dengan tema yang ditentukan, rata-rata siswa telah mampu menuliskan bagian-bagian struktur teks deskripsi. berdasarkan teks deskripsi yang dibuat siswa, pembaca bisa melihat struktur yang sesuai dan sistematis, yaitu deskripsi umum, deskripsi bagian, dan penutup. Oleh karena itu, pada indikator struktur teks deskripsi siswa telah mendapatkan niai yang baik.

Ketiga, Indikator 3 (memahami ciri kebahasaan teks deskripsi). Indikator ciri kebahasaan teks deskripsi dengan nilai rata-rata 75,00 berada pada kualifikasi lebih dari cukup. Skor yang diperoleh siswa untuk indikator ciri-ciri kebahasaan teks deskripsi adalah sebagai berikut. Siswa yang memperoleh nilai 100,00 dengan kualifikasi sempurna berjumlah 7 orang $(16,67 \%)$. Siswa yang memperoleh nilai 83,33 dengan kualifikasi baik berjumlah 18 orang $(42,86 \%)$. Siswa yang memperoleh nilai 66,67 dengan kualifikasi lebih dari cukup berjumlah 7 orang $(16,67 \%)$. Siswa yang memperoleh nilai 50,00 dengan kualifikasi hampir cukup berjumlah 9 orang $(21,43 \%)$. Siswa yang memperoleh nilai 33,33 dengan kualifikasi kurang sekali berjumlah 1 orang $(2,38 \%)$.

Berdasarkan hasil tersebut, disimpulkan bahwa rata-rata hitung keterampilan menulis teks deskripsi siswa kelas VII SMP Negeri 15 Padang yang tertinggi berada pada indikator 2 (struktur teks deskripsi) dan terendah berada pada indikator 3 (ciri kebahasaan teks deskripsi). Berdasarkan uraian tersebut, dapat disimpulkan bahwa nilai rata-rata keterampilan menulis teks deskripsi siswa secara umum sebesar 79,37 dan berada p ada kualifikasi baik.

\section{Korelasi Keterampilan Menulis Teks Deskripsi dengan Keterampilan Menulis Teks Deskripsi Siswa Kelas VII SMP Negeri 15 Padang}

Untuk mencari korelasi keterampilan memahami teks deskripsi terhadap keterampilan menulis teks deskripsi siswa kelas VII SMP Negeri 15 Padang terlebih dahulu dicari korelasi kedua variabel tersebut. Korelasi keterampilan memahami teks deskripsi dengan keterampilan menulis teks deskripsi siswa kelas VII SMP Negeri 15 Padang dicari dengan menggunakan rumus korelasi product moment. Nilai keterampilan memahami teks deskripsi dimasukkan ke dalam variabel $\mathrm{X}$ dan nilai keterampilan menulis teks deskripsi dimasukkan ke dalam variabel $\mathrm{Y}$. Data variabel bebas memiliki korelasi dengan variabel terikat karena $r_{\text {hitung }}>r_{\text {tabel }}(0,853>$ $0,304)$.

Nilai korelasi kedua variabel dalam penelitian ini adalah 0,853. Untuk menafsirkan keberartian hubungan antara kedua variabel setelah nilai koefisien korelasi diperoleh, dilanjutkan dengan uji keberartian hipotesis. Setelah itu, dilanjutkan dengan membandingkan nilai $t_{\text {tabel }}$ dengan $t_{\text {hitung }}$ pada taraf nyata 0,05 dengan derajat kebebasan $n-1$.

Dari hasil pengujian hipotesis tersebut, dapat disimpulkan bahwa terdapat korelasi antara keterampilan memahami teks deskripsi dengan keterampilan menulis teks deskripsi pada taraf nyata 0,05 dengan derajat kebebasan n-1 $(42-1=41)$. Berdasarkan hal tersebut, berarti terdapat korelasi yang signifikan antara keterampilan memahami teks deskripsi terhadap keterampilan menulis teks deskripsi siswa kelas VII SMP Negeri 15 Padang. $\mathrm{H}_{0}$ dalam penelitian ini ditolak, sedangkan $\mathrm{H}_{1}$ diterima karena hasil pengujian membuktikan bahwa $t_{\text {hitung }}$ lebih besar dari $t_{\text {tabel }}$ yaitu 10,32 > 1,68. Dengan demikian dapat diketahui bahwa keterampilan memahami teks 
deskripsi berkorelasi dengan ketermpilan menulis teks deskripsi siswa kelas VII SMP Negeri 15 Padang.

\section{Simpulan dan Saran}

Berdasarkan hasil analisis disimpulkan tiga hal sebagai berikut. Pertama, keterampilan memahami teks deskripsi siswa kelas VII SMP Negeri 15 Padang berada pada kualifikasi Baik (B) dengan nilai rata-rata 80,54. Kedua, keterampilan menulis teks deskripsi siswa kelas VII SMP Negeri 15 Padang berada pada kualifikasi Baik (B) dengan nilai rata-rata 79,37. Ketiga, berdasarkan hasil uji-t, disimpulkan bahwa terdapat hubungan yang signifikan antara keterampilan memahami teks deskripsi dengan keterampilan menulis teks deskripsi siswa kelas VII SMP Negeri 15 Padang karena nilai $t_{\text {hitung }}>t_{\text {tabel }}(10,32>1,68)$ " $t_{\text {hitung }}$ lebih besar daripada tabel". Jadi, dapat disimpulkan bahwa keterampilan memahami teks deskripsi mempunyai korelasi dengan keterampilan menulis teks deskripsi siswa kelas VII SMP Negeri 15 Padang.

Berdasarkan simpulan tersebut, dikemukakan tiga saran sebagai berikut. Pertama, disarankan kepada guru mata pelajaran bahasa Indonesia kelas VII SMP Negeri 15 Padang untuk lebih meningkatkan keterampilan membaca pemahaman siswa, khususnya dalam pembelajaran keterampilan memahami teks deskripsi. Hal ini disebabkan karena keterampilan memahami teks deskripsi erat hubungannya dengan keterampilan menulis teks deskripsi.

Kedua, disarankan kepada siswa terutama siswa kelas VII SMP Negeri 15 Padang untuk lebih banyak berlatih menulis baik di sekolah maupun di luar sekolah agar keterampilan menulis terutama menulis teks deskripsi dapat dikembangkan dengan baik, lebih terstruktur, dan berdaya guna.

Ketiga, disarankan kepada peneliti lain sebagai masukan dan perbandingan dalam melakukan penelitian yang berkaitan dengan masalah ini. Selain itu, supaya dapat melakukan penelitian komprehensif, baik mengenai keterampilan memahami teks deskripsi, keterampilan menulis teks deskripsi, maupun aspek-aspek terkait lainnya.

Catatan: Artikel ini disusun berdasarkan skripsi Deta Fitrianita dengan Pembimbing I Prof. Dr. Syahrul R., M.Pd. dan Pembimbing II Dr. Tressyalina, M.Pd.

\section{Daftar Rujukan}

Arikunto, S. (2010). Prosedur Penelitian Suatu Pendekatan Praktek. Jakarta: Rineka Cipta.

Febriyeni. (2014). Kemampuan Menulis Paragraf Deskripsi siswa Kelas X SMA Negeri 2 Tanah Sepenggal Kabupate Bungo Tahun Ajaran 2013/2014. Journal UNJA 14(5):5—5.

Ibnu, S., Moehnilabib, B. M., Mukhadis, A., Suparno, Rafi'udin, A., dan Sukarnyana, I. W. (2003). Dasar-dasar Metodologi Penelitian. Malang: Universitas Negeri Malang.

Kemendikbud. (2014). Bahasa Indonesia Ekspresi Diri dan Akademik Edisi Revisi. Jakarta: Kementrian Pendidikan dan Kebudayaan.

Kosasih, dkk. (2016). Bahasa Indonesia untuk SMP/MTs Kelas VII. Buku Siswa. Jakarta: Kementrian Pendidikan dan Kebudayaan.

Langi, A., Tahir, M., dan Idris. (2015). Peningkatan Kemampuan Membaca dan Menulis. Jurnal Kreatif Tadiulako 4(8):89-89. 
Korelasi Keterampilan Memahami Teks Deskripsi dengan Keterampilan Menulis Teks Deskripsi Siswa Kelas VII SMP Negeri 15 Padang-Della Melaty, Irfani Basri, M. Hafrison

Manaf, N. A. (2010). Semantik Bahasa Indonesia. Padang: UNP Press.

Nazir, M. (2010). Metode Penelitian. Bogor: Ghalia Indonesia.

Oktaviani, N., Aminah, S., dan Susanti, R. (2009) Sinonim, Repetisi, dan Antonim. Jurnal Lingua Cultura 3(1):38-38.

Pujiono, S. (2012). Berpikir Kritis dalam Literasi Membaca dan Menulis. Jurnal Unsoed 16(4):781-781.

Rozelin, D. (2012). Analisis Preposisional dalam Tajuk Wacana Berita di Kompas, Solo Pos, dan Republika. Media Akademika 27(2):256-256.

Samniah, N. (2016). Kemampuan Memahami Isi Bacaan siswa. Jurnal Humanika 16(1): 1—1.

Siswartini. (2014). Meningkatkan Kemampuan Siswa Menulis Laporan Perjalanan Melalui Latihan Terbimbing di Kelas VIII 6 SMP Negeri 21 Batanghari. Jurnal UNJA 6(4):2-2.

Suyuno. (2008). Pembelajaran Efektif dan Produktif. Jurnal UM 14(2):204-204.

Wahyuni, S. (2009). Menumbuhkembangkan Minat Baca Menuju Masyarakat Literat. Jurnal Ilmiah Bahasa, Sastra, dan Pengajarannya. 16(2):180-180.

Zaimar, K. S. (2002). Majas dan Pembentukannya. Makara, Sosial Humaniora. 6(2):45—45. 